NBER WORKING PAPER SERIES

\title{
OVERSEAS ASSEMBLY AND COUNTRY SOURCING CHOICES
}

\author{
Deborah L. Swenson \\ Working Paper 10697 \\ http://www.nber.org/papers/w10697 \\ NATIONAL BUREAU OF ECONOMIC RESEARCH \\ 1050 Massachusetts Avenue \\ Cambridge, MA 02138 \\ August 2004
}

The views expressed herein are those of the author(s) and not necessarily those of the National Bureau of Economic Research.

(C)2004 by Deborah L. Swenson. All rights reserved. Short sections of text, not to exceed two paragraphs, may be quoted without explicit permission provided that full credit, including $(\mathcal{C}$ notice, is given to the source. 
Overseas Assembly and Country Sourcing Choices

Deborah L. Swenson

NBER Working Paper No. 10697

August 2004

JEL No. F1

\section{ABSTRACT}

This paper studies the cross-country pattern of U.S. overseas assembly activities between 1980 and 2000 to examine how outsourcing decisions are affected by changes in country and competitor costs. A number of interesting regularities emerge. When a country's costs rise, the share of U.S. overseas assembly activities in that location decline. Conversely, a country's share of U.S. overseas assembly activities grows when competitor country costs increase. While own and competitor country costs affect overseas assembly in all countries, the magnitude of these effects is larger for developing countries than it is for developed countries. In many cases, the measured responses to cost changes appear to correspond with outsourcing theories that are based on search and customization costs.

Deborah L. Swenson

Department of Economics University of California

One Shields Avenue

Davis, CA 95616

and NBER

dswenson@ucdavis.edu 
Production and trade increasingly involves the flow of intermediate goods from one county to the next as multiple countries complete successive steps in a globally integrated production process. ${ }^{1}$ As outsourcing activities grow in importance, they fuel public concern that firms will immediately relocate their production facilities whenever wages and costs in the current location rise above those available elsewhere. However, more nuanced treatments of outsourcing decisions recognize that location decisions require more than a simple cross country comparison of wages. As recent work by Grossman and Helpman (2002) demonstrates, a high wage country may continue to attract outsourcing firms if it offers better infrastructure, partners who are skilled in adapting their capabilities to the needs of the outsourcing firms, or highly effective legal protections that secure outsourcing relationships. Nonetheless, while it is well understood that the location of outsourcing production should reflect differences in country costs, there is little known about actual outsourcing decisions. ${ }^{2}$

To examine how costs affect outsourcing decisions, I study U.S. outsourcing conducted between 1980 and 2000 through the provisions of the offshore assembly program (OAP) which is known as 9802 in the current U.S. tariff code. The benefit of studying the OAP program is that it presents a direct view of one portion of outsourcing activities, since the program was specifically designed to provide tariff benefits to firms whose exports to the U.S. contain U.S.-produced parts or materials. In particular, when such products enter the U.S., tariffs are due on the foreign portion of value added, but not

\footnotetext{
$1 \quad$ Hummels, Ishii \& Yi's (2001) calculations suggest that vertical specialization now accounts for 30 percent of all trade flows. See Feenstra (1998) for a survey and description of trends in international outsourcing.

${ }^{2}$ Gorg's (2000) study of US outsourcing in the EU is one exception. In related work, Swenson (1999), Feenstra, Hanson and Swenson (2000), and Hanson, Mataloni and Slaughter (2003) examine how the share of parent inputs in outsourcing production is affected by costs.
} 
on the U.S. parts and components that are contained in the assembled good. As a result, the administration of OAP activities creates a data trail that allows one to examine how cross-country sourcing patterns respond to changes in country cost conditions. The data from this program are very rich, as OAP outsourcing involved almost 400 four-digit SIC industries, and more than 60 countries who frequently provided assembly services. Further, while imports entering through the OAP program do not include all outsourcing activities related to the U.S., they do represent a non-trivial portion of U.S. trade. ${ }^{3}$ Another benefit of studying outsourcing activities conducted through OAP is that use of OAP data enable one to construct detailed cost measures by country and industry that account for production techniques, as well as country, tariff and transportation costs.

By studying evolution of OAP outsourcing patterns over time, this paper analyzes how cost conditions affect outsourcing. The results show that the share of any industry OAP outsourcing conducted in a country is responsive to that country's costs as well as changes in their competitors' costs. The share of OAP imports purchased from a particular country in a given industry declines when the country's costs increase, and grows when competitor country costs for that industry rise.

More important, by showing how country or industry characteristics condition the degree of cost responsiveness I provide evidence that is consistent with outsourcing theories that are based on information search, or development costs. In this regard country development, is highlighted for a number of reasons. First, if more developed countries produce goods that are more highly differentiated than those originating from developing countries, cost changes may exert a greater influence on decisions about the

\footnotetext{
${ }^{3}$ OAP imports constituted 9.6 percent of U.S. goods imports during the sample period, 1980-2000. OAP imports were $11.7 \%$ of U.S. goods imports between 1980 and 1990, and 8.3\% for 1991-2000.
} 
more homogenous products assembled in developing countries. Further, higher skill levels in developed countries may also provide better insulation from cost-based production shifts. To the extent that lower skilled workers are more interchangeable, there may be fewer frictions that prevent the movement of simple assembly operations from one low wage developing country to the next, such as the search costs that are highlighted in Grossman and Helpman(2004). The empirical analysis confirms the importance of development differences, showing that developing countries are more adversely affected by increases in their own costs, or declines in competitor costs than are developed countries. Of industry characteristics, capital intensity figures most prominently. Here, the allocation of outsourcing activities in less capital intense industries responds more vigorously to cost changes than outsourcing activities in more capital intense industries, further suggesting that outsourcing theories based on search costs and tailoring of the production process are consistent with the data.

The rest of the paper is organized as follows. To motivate the regression analysis, section two describes recent models of outsourcing, highlighting the role of country or industry characteristics in enhancing or reducing the overall sensitivity of outsourcing to costs. Section two also describes the OAP data that are the basis for this project. Section three provides a model of outsourcing production decisions, which is then estimated in Section four. A brief conclusion follows in section five. 


\section{Outsourcing and Trade Background}

Cross country factor cost differences may create an incentive to engage in outsourcing, as firms decide where to complete the different production stages - design, materials extraction, parts production, and assembly - that are required for the creation of a final product. As with trade in final products, comparative advantage determines the ideal country placement for each production stage. ${ }^{4}$

However, while one expects outsourcing decisions to respond to country cost conditions, it is not obvious that outsourcing production will respond quickly or substantially to all cost changes. As Rauch (1999) highlights, information appears to play a large role in determining trade volumes, especially for differentiated products. As a result, even when country costs change, firms may not be sufficiently well informed about other markets to quickly change the location of their international sourcing. Grossman and Helpman's (2004) recent work on international outsourcing includes just such an informational feature; when Northern firms seek partners they must expend resources on information gathering as they search for potential partners who match their production requirements. In this context, Northern firms may be dissuaded from seeking outsourcing partners in the low wage South if the fixed costs of information gathering are high in those locations. Similarly, if a firm is hit by a cost shock in one country where it operates, it may only seek information on alternative outsourcing partners if the shock is sufficiently large to warrant the expenditures involved in finding a new partner. ${ }^{5}$

\footnotetext{
4 As Deardorff(2001) shows outsourcing may facilitate factor price equalization in settings where ordinary goods trade would not suffice.

5 This would be consistent with hysteresis, as described by Baldwin (1988), Baldwin and Krugman (1989), Dixit (1989), Krugman (1989), or Tybout and Roberts (1999).
} 
Since there dramatic differences in skill levels by country development it seems very likely that the search costs Grossman and Helpman (2004) feature in their models will be much higher for developed country projects than they are for developing country outsourcing projects. If developing country outsourcing assembly is typified by low-skill assembly activities performed by low wage workers, it may not be difficult for firms to compare their options across developing country locations. If this is true, then developing country outsourcing decisions should respond more vigorously to cost changes, since the fixed costs of search are proportionately smaller than they are in cases where highly skilled, and highly specialized assembly facilities are required.

This same argument may distinguish the difficulty of relocating a highly detailed production processes versus those that are less differentiated and complex. Search costs, and the costs of relationship-specific investments described by Grossman and Helpman (2004) are likely to be higher for more complicated assembly tasks. If capital intense projects have higher search costs, and entail more tailoring of production to meet the outsourcing firm's production requirements, capital intense industries are likely to exhibit a smaller responsiveness to cost changes. ${ }^{6}$ To explore this possibility, I test whether less capital intense industries are more cost sensitive than those that have highly capital intensive production processes.

\footnotetext{
${ }^{6}$ In a related vein, Qui and Spencer (2002) show how trade policy loses its potency when relationshipspecific investments cause firms to purchase intermediate inputs from affiliates rather than unrelated parties.
} 


\subsection{A Description of OAP and Outsourcing Trends}

The data for this project track U.S. outsourcing conducted through the OAP program between the years 1980 and 2000. While it is now referred to as 9802 in the U.S. tariff code, the U.S. Overseas Assembly Program originated with the Tariff Act of $1930 .^{7}$ The OAP program provides tariff benefits for producers whose products were assembled abroad using U.S.-origin parts, components or materials. When OAP products arrive in the U.S., tariffs are levied only on the value-added that was generated abroad, while the product value attributable to U.S. parts and components is exempt. ${ }^{8}$ Since administration of the OAP program requires importers to provide information about the composition of their products, and whether the value of the product is attributable to dutiable OAP import or non-dutiable U.S.-origin components, its operation creates an opportunity to directly observe one component of U.S. outsourcing activities.

Figure 1 displays the broad expansion of OAP imports between 1971 and 2000. Over this period the real value of OAP imports grew more than 400 percent in value. While this represents a substantial growth rate, OAP outsourcing did not grow as quickly as outsourcing measured in Hummels, Ishii and Yi (2001), possibly since the desirability of OAP assembly was inhibited by the requirement of using U.S. inputs which were likely to be relatively expensive, even after the tariff preference. There is one large spike in OAP imports in the late 1980's that disappears by the early 1990's. Further examination of the data at a more disaggregated level shows that the spike is driven by a surge in OAP auto imports from all major partners in the late 1980's. If auto activities are

\footnotetext{
7 This program was called 806/807 in the TSUSA based U.S. tariff code. It was renamed 9802 when the U.S. moved to the Harmonized System in 1989.

8 Hanson (1997) provides a history of the program.
} 
removed from the series, the time pattern of OAP imports exhibits a smooth, though slower sustained growth during the late 1980's and beginning of the $1990{ }^{\prime}{ }^{9}{ }^{9}$

Figure 1 also displays the breakdown of total OAP imports between dutiable OAP import value and non-dutiable U.S. materials and components. In all years, the value of dutiable foreign-source OAP activities exceeded the value of the U.S. inputs contained in OAP products.

\subsection{The OAP data sample}

In this project, the unit of analysis is the 4-digit SIC OAP imports by country. Due to concordance and data limitations, the data set is divided into two data panels, the first for 1980-1990 which is analyzed using 1972-definition SIC codes, and the second for 1991 to 2000 which is based on 1987-definition SIC codes. Each of the data panels includes almost 400 4-digit SIC industries, and OAP imports from more than 60 countries. Appendix 1 lists the countries that are included in the analysis. ${ }^{10}$ Notably, OAP imports originated not just from low income locations that are known for their assembly operations, but also from a full array of richer countries.

Since this paper seeks to show how competitive pressures affect the location of sourcing activities, it is important to characterize which countries were in competition with each other. As Grossman and Helpman (2002, 2004) demonstrate, it is not reasonable to assume that all low wage countries are viable outsourcing candidates based on their low costs alone. In particular, a low wage country can lose its attractiveness as

\footnotetext{
9 The spike in program usage does not influence the general findings presented later. If transportation (SIC 37) or automobiles (SIC 371) are removed from the sample the general results do not change.

10 Countries were included in the sample if they had 10 or more positive OAP shipment observations in the panel.
} 
an outsourcing location if its wage advantage is more than offset by an absence of suitable facilities, legal protections, infrastructure or worker skills. In addition, transportation costs may also remove the country from consideration as a potential supplier.

To create a manageable definition of competition, countries are defined as a potential supplier, or competitor for a particular 4-digit SIC industry if the country exported OAP products in that 4-digit SIC during any of the years in the sample period. While this definition excludes countries that were considered but never selected, the advantage of defining competitors more narrowly is that it prevents the false inclusion of countries that never exerted competitive pressures in the industry. ${ }^{11}$

Using this definition, Table 1 summarizes the variation in the number of competitor countries by industry for both the early 1980-1990 and late 1991-2000 data panels. When the data are organized by 2-digit industry, cross industry differences in competition become apparent. As might be expected, the largest number of competing countries was present in Textiles and Apparel. Within textiles and apparel, the typical 4digit SIC industry received OAP imports from 41 countries in the early years, and 39 countries in the later panel. The presence of competitors in the 2-digit industries is very consistent across the two time periods.

\footnotetext{
${ }^{11}$ This approach is similar to that of Goldberg and Knetter (1999), which defines competitors as countries that also export a product and have a reasonably large market share. Further, if the panels were instead created by following all SIC industries, for all countries in the sample period, fewer than 10 percent of the country-industry-year import observations would be non-zero.

Other authors including Schott (2002) or Bernard and Jensen (2002) focus on low wage competition. However, this study is unable to exploit Schott's definition of low wage competitors since very few OAP imports were purchased from Schott's sample of especially "low wage" countries.
} 


\section{A Model of OAP Outsourcing}

In order to estimate how costs affect the location of OAP activities it is necessary to specify a model of outsourcing decisions. To do this, I begin with a simple reduced form model that is sufficiently flexible to include the economic variables of interest, and to assess whether the allocation of OAP production across countries is consistent with predictions from the outsourcing literature.

The simple equation relates the share of OAP imports $\mathrm{SHR}_{\text {ict }}$ purchased in industry $i$ from country $c$ in year $t$ to the number of potential providers $n_{i}$, and to economic factors $\mathrm{X}_{\mathrm{ict}}$ that are discussed in the literature on outsourcing and international trade. $^{12}$

(1) $\quad \mathrm{SHR}_{\text {ict }}=\gamma\left[1 / \mathrm{n}_{\mathrm{i}}\right]+\beta \mathrm{X}_{\mathrm{ict}}+\varepsilon_{\text {ict }}$,

As discussed in Section 2, the number of competitor countries $n_{i}$ is defined as the number of countries during the sample period that ever provided U.S. OAP imports in a particular 4-digit industry. In any given year the number of potential providers $n_{i}$ is almost always larger than the actual number of providers since most country-industry OAP producers experienced at least a few years for which their OAP exports were zero. If OAP products are differentiated by country of assembly, and consumer utility is characterized by a love of variety, then we would expect that each provider would ship an equal share, $\left[1 / n_{i}\right]$, if all economic factors were equal, and all potential providers were in the market.

However, OAP production opportunities do differ in a number of fundamental

\footnotetext{
${ }^{12}$ The dependent variable is constructed as $\operatorname{SHR}_{\text {ict }}=\left(\right.$ OAP Customs Value $\left.{ }_{\text {ict }}\right) / \sum_{\mathrm{c}}\left(\mathrm{OAP}\right.$ Customs Value $\left.\mathrm{ict}_{\text {ict }}\right)$.
} 
ways which are captured by the explanatory variables in $\mathrm{X}_{\mathrm{ict}}$. These include regressors, such as country GDP, GDP per capita, and distance from the U.S. that are commonly included in gravity or other reduced form estimates of trade volumes. The vector of explanatory variables also includes detailed measures of production costs that account for production techniques, transportation costs, and the tariff treatment of OAP products from a country. The set of explanatory variables also includes a measure of competitor country costs. As predicted by all outsourcing theories, a rise in own costs in country c, should depress the share of outsourcing activities conducted in that location. In contrast, a country is expected to benefit from the ability to sell a greater share of OAP products when the costs of its competitors rise. The final components of $X_{\text {ict }}$ include a full set of country and industry dummy variables. The general equation is first run using Tobit techniques, since there are many observations where the country share of industry $i$ is zero and a small handful where the share is one. ${ }^{13}$

To better account for heterogeneity across industries and countries, such as the more subtle variation resulting from industry comparative advantage by country, most of the regressions rely on random effects Tobit estimation instead, where the error term takes the form:

$$
\varepsilon_{\text {ict }}=\theta_{\text {ic }}+\eta_{\text {ict }}
$$

which includes a country-industry effect $\theta_{\text {ic }}$ as well as an iid disturbance $\eta_{\text {ict. }}$. A primary benefit of these techniques is that the country-industry effect can help to control for factors that condition the suitability of a country for provision of OAP products in industry i that are otherwise unobservable.

\footnotetext{
13 In studying U.S. import data at the product level, Besedes and Prusa (2001) document the prevalence of zero trade flows due to the intensity of entry in to and out of importing generally.
} 


\subsection{Cost Measurement}

Before the share equation can be estimated it is important to generate measures of own and competitor country costs. I exploit the details of the OAP program, to create highly detailed cost measures that relate to production techniques, production costs, transportation costs, and tariffs. I then combine these measures with my earlier definition of competition to create competitor cost measures.

The literature on vertical integration traditionally begins with a Leontieff production function. ${ }^{14}$ In modeling the structure of OAP costs, I assume that OAP production requires producers to complete a series of $\mathrm{m}_{\mathrm{i}}$ tasks that must be performed in order beginning at task 0 and ending with task $m_{i}$ which is the final assembly task. A fraction of those tasks, which is represented by the activities from 0 to $\alpha_{\text {us }}$, involves the production of parts and materials in the U.S. The remaining activities from $\alpha_{u s}$ to $m_{i}$ are performed in a foreign location. The fact that a producer is using the OAP program implies that the U.S. has comparative advantage in the early stage tasks, while the foreign country has comparative advantage final assembly, and possibly some other late stage tasks as well. The actual position of $\alpha_{\text {us }}$ will differ by country and industry, taking a value $\alpha_{\text {us,ic }}$ that reflects the relative productivity of the U.S. versus the foreign country in the industry, as well as tariffs and the transportation costs for the country-industry pair.

\footnotetext{
${ }^{14}$ See Greenhut and Ohta (1979), or Mendez (1993) for an application to OAP. Yi (2003) creates a more elaborate three stage production structure.
} 


\section{International Task Allocation}

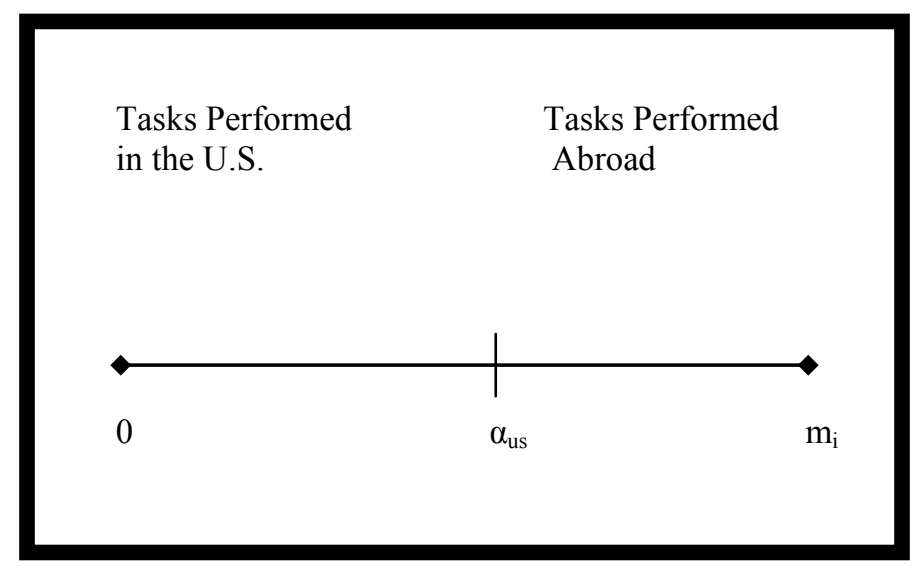

If a project requires $L_{i}$ units of labor, and each of the $m_{i}$ tasks in the project requires $L_{i} / m_{i}$ units of labor, the total production cost for the product will be: ${ }^{15}$

\section{(3) Production Cost $\left.\mathrm{ic}_{\mathrm{ic}}=\left[\alpha_{\mathrm{us}, \mathrm{ic}}{ }^{*} \mathrm{w}_{\mathrm{us}}+\left(1-\alpha_{\mathrm{us}, \mathrm{ic}}\right) * \mathrm{w}_{\mathrm{c}}\right)\right]^{*} \mathrm{~L}_{\mathrm{i}}$}

where the $\alpha_{\mathrm{us}, \mathrm{ic}}$ U.S. tasks require U.S. labor which costs $\mathrm{w}_{\mathrm{us}}$ per unit, while the cost of foreign labor for the $\left(1-\alpha_{u s, i c}\right)$ tasks performed abroad is $w_{c}$.

Completing OAP products involves two further costs. First, an ad valorem transportation cost $g_{\text {ic }}$ applies not only to the shipment of the final product to the U.S., but also to the shipment of the $\alpha_{\mathrm{us}, \text { ic }}$ U.S. intermediate inputs to the assembly location. Second, the foreign value added $\left(1-\alpha_{\text {us,ic }}\right)$ is subject to U.S. import tariffs at a rate $\tau_{\mathrm{i}}$. Adding these elements to the underlying production cost yields the total cost of OAP sourcing:

$$
\left.\mathrm{C}_{\mathrm{ic}}=\left[\alpha_{\mathrm{us}, \mathrm{ic}} * \mathrm{w}_{\mathrm{us}}+\left(1-\alpha_{\mathrm{us}, \mathrm{ic}}\right) * \mathrm{w}_{\mathrm{c}}\right)\right]^{*} \mathrm{~L}_{\mathrm{i}} *\left[1+\mathrm{g}_{\mathrm{ic}}\left(1+\alpha_{\mathrm{us}, \mathrm{ic}}\right)+\left(1-\alpha_{\mathrm{us}, \mathrm{ic}}\right) * \tau_{\mathrm{i}}\right]
$$

The cost measure is created by following this formula, using the data that are described in

15 Time subscripts are omitted for simplicity. 
the data appendix. ${ }^{16}$

To quantify competitive pressures exerted by competitor countries, Competitor

Cost creates the weighted average of competitor country costs, where weights are based on the real value of OAP imports $\mathrm{V}_{\mathrm{ci}}$ for all countries $\mathrm{c}$ producing in industry $\mathrm{i}$. The competitor cost measure for country $c^{\prime}$ in year $t$ is defined as:

$$
\text { CompetitorCost } t_{c^{\prime} i}=\sum_{c \neq c^{\prime}}\left[\frac{V_{c i}}{\sum_{c \neq c^{\prime}} V_{c i}} * C_{i c}\right]
$$

Costs for each country c, $\mathrm{C}_{\mathrm{ic}}$, are measured using the cost formula given by (4). The competitor cost measure is computed using 1980 and 1990 value weights in the first panel, and 1991 to 2000 value weights in the second panel. An increase in the Competitor Cost variable indicates that competitor country costs have risen.

\footnotetext{
${ }^{16}$ I assume that the cost of transporting inputs in industry $\mathrm{i}$ is the same as the cost of transporting final goods in industry i, since I do not have detailed information on composition of input trade that would enable me to use transportation costs for the U.S. inputs that are shipped abroad for foreign assembly. To proxy country costs, I used the Penn World Table, $\mathrm{P}$, which is the price level of gross domestic product. Since I assume that the labor needed to produce a product, $\mathrm{L}_{\mathrm{i}}$, is the same for all locations, it should be viewed as a scaling factor that will not influence country shares. It is removed from equation (4) since there is no good measure by industry. Finally, to complete the cost calculation I use the average value of $\alpha_{\mathrm{us}, \text { ic }}$ for an industry-country over the sample period. While the magnitude of $\alpha_{\mathrm{us}, \mathrm{ic}}$ does vary with the relative cost of sourcing in country c compared to the cost of production in the U.S., the economic effects of these shifts, as in Swenson (1999) are small.
} 


\subsection{Results}

The primary estimating equation relates the share of U.S. OAP imports from different countries to cost and economic conditions that influence the attractiveness of outsourcing in different locations. After exploring the effects in the full sample, the effects by development, industry and country are investigated.

The consistent message of the analysis is that costs do influence the location of outsourcing. As Table 2 shows, a country's share of OAP outsourcing falls if the country's costs increase and the country's share grows when its competitors' costs rise. The results emerge in both the early 1980-1990 panel and the late 1991-2000 panel, whether the estimates are done by Tobit with full sets of country and industry dummies, as displayed in columns (1) and (2), or by random effects Tobit.

While the first columns of Table 2 provide a baseline Tobit for comparison, my preferred method of estimation is random effects Tobit. One reason for including country-industry effects is to capture unobservable features, the most notable of which includes comparative advantage at the country-industry level that influences the desirability of assembling industry i goods in country c. Another benefit of using random effects Tobit is that it enables me to estimate the effect of time-invariant economic factors that influence outsourcing, such as distance, whose effects are otherwise subsumed in the country controls.

Since changes in outsourcing are likely to require time, to enable firms to search for new partners and write new contracts or to build new assembly facilities, the regressions are based on own and competitor cost measures that are lagged two periods. 
However, the decision to lag the cost measures two periods is not critical, as the results for a one period lag are almost identical. ${ }^{17}$

The own cost coefficients imply that a ten percent increase in own costs would have reduced the outsourcing share by 1.7 percent in the $1980-1990$ interval, or by 0.8 percent in the later panel. While these numbers may not seem large, they are relatively large when compared with the average share provided by countries, which was $4.6 \%$ for $1980-1990$, and 5.6 for $1991-2000 .^{18}$

Columns (3) and (4) of Table 2 show that high GDP per capita is found to reduce a country's share of OAP activity. However, one might be concerned that GDP measures, because they contain information on country costs, will influence the estimated magnitude of the own country cost measures. To investigate this possibility, the GDP measures are removed from the regressions displayed in columns (5) and (6). The magnitudes of the estimated cost coefficients all rise slightly as compared with the regression results shown in columns (3) and (4). However the fit of the regressions also falls. For that reason, the GDP measures are included in the remaining regressions, though it should be recognized that their inclusion seems to reduce the estimated magnitude of the cost coefficients by a small amount.

Notably, even though the measures of cost explicitly include the cost of transporting items in industry i from country c to the U.S., as well as the cost of moving

17 For example, if I re-estimate the specifications shown in columns (3) and (4) of Table 2 using costs that are lagged only a single period, the values for own cost and competitor cost are -.177(.011) and .169(.008) in a revised column (3), and -.078(.012) and .295(.007) in a revised column (4). However, the loglikelihoods of the revised regressions, $-17,614$ and -14,563 imply that the fit of the two lag specification is better than the single lag specification. Further, if cost measures for one and two lags are included in a single specification, the magnitude and significance of the coefficients on the two lag measures exceeds that of the coefficients on the single lag measures.

${ }_{18}$ The average share provided, if zero observations are excluded, is $13.7 \%$ in the early years, and $13.5 \%$ in the late years. 
intermediate inputs to the assembly country, distance is found to further reduce a country's share of OAP assembly. These results are consistent with recent work suggesting that distance reduces trade not only due to the cost of moving items, but also due to the time disadvantage of being located far from customers. ${ }^{19}$ It is also worth noting that the coefficient on distance is smaller in the later panel than it is for the earlier years, as might be the case if communications improvements over time reduced the delays associated with more distant outsourcing partners.

To control for the number of potential partners, and to gauge the range of substitution opportunities, I use the term (1/\# of Competitors), which is based on the number of countries who provided goods in the same 4-digit industry over the sample periods. The results show that country shares of OAP activity are higher for supplier countries who face fewer competitors. Partner density can alternatively be measured by the count of contemporaneous competitors supplying the industry. However, the choice of competitor count measure does not seem to affect the estimated magnitude or significance of the primary coefficients of interest.

Finally, it is interesting to note that controls for industry capital intensity, measured by the capital intensity of the U.S. industry, have significantly different coefficients depending on whether the OAP activity is conducted in a developed or developing country. ${ }^{20}$ This evidence is consistent with Head and Ries's (2002) findings

\footnotetext{
19 See Hummels(2001) and Evans and Harrigan(2003).

20 I make the assumption that the capital intensity of outsourcing operations is positively correlated with the capital intensity of the U.S. industry. While it would be desirable to have direct measures of capital intensity in outsourcing operations, no such measures exist.

The coefficients on the developed country and developing country capital intensity coefficients are almost always statistically distinct. Allowing for separate coefficients improves the regression fit compared with a baseline that has a single capital intensity regressor for all countries.
} 
that suggest that Japanese firms hire less skilled workers in low income locations, and higher skilled workers in high income countries.

The initial regression specification assumes that the regression coefficients are the same for all sourcing relationships, with the exception of the coefficients on capital intensity, which are allowed to differ for developed and developing countries. However, as section 2 notes, there are a many reasons why outsourcing may react differently to cost changes or other economic factors, depending on whether the overseas assembly is located in a developed or a developing country.

To examine the issue further, the effects of development on sourcing choices are explored in Tables 3 and 4, which consider 1980-1990 and 1991-2000 OAP outsourcing in turn. I use two alternative definitions of development. The first defines a country as "developed" if it was a member of the OECD in 1985. The second definition classifies countries as developed if the average education of the adult population exceeded 6 years. $^{21}$

What is interesting are the systematic differences between the estimated coefficients for developing and developed countries. As in the full sample, the new results suggest that own cost increases reduce the share of the market provided by a country, while competitor cost increases boost the country's share. However, in all cases the effect of own cost changes is more pronounced for developing countries than it is for developed countries, implying that cost rises are more harmful to developing country shares of OAP than they are for developed country shares. In addition, the results also

\footnotetext{
${ }^{21}$ The classification was based on educational attainment in 1990 in Barro and Lee, for adults 25 or older. I adopt Riker and Brainard's (1997) use of 6 or more years education as the definition of a high education country, which I define as "developed" countries.
} 
suggest that developing countries are more strongly benefited by increases in competitor costs. $^{22}$ Another dichotomy that is interesting is the fact that the detrimental effect of distance on OAP share is stronger for developing countries in three of the four regressions.

I now use distinct measures of competitor numbers for developed and developing countries to reflect differential substitution opportunities. In particular, if workers in developed countries are more skilled, it is likely that they perform activities that are more complexly tailored, and their particular skills may not be replaceable in developing locations. To reflect these differences, for developed country observations competition is measured by the number of developed country competitors in the industry. Similarly, competition for developing country observations is measured by the count of developing country competitors in industry. As with the other variables, the competitor counts are based on the definition of development. In the first set of regressions, the competitor counts are based on the OECD definition, while the counts are based on the 6 year education threshold in the second set of regressions. The results in Tables 3 and 4 support the idea that the pool of competitors has a differential effect on developing and developed countries. However, while the effects are statistically distinct, the measured effects differ with the definition of development.

Industry capital intensity may also condition the flexibility of outsourcing movements across countries. If components produced for more capital intense industries are generally more differentiated, specialized or complex, firms will have to conduct

\footnotetext{
${ }^{22}$ The one perverse coefficient is the negative sign on competitor cost, for OECD countries providing OAP products between 1991 and 2000. If the GDP terms are eliminated from the regression, the competitor costs are as expected, taking a value of .291(.011) for the OECD and .351(.011) for the non-OECD, while the own cost coefficients are -.038(.025) for the OECD and -.166(.013) for the non-OECD.
} 
more involved searches to identify partners who are capable of assembling these components into final products. In addition, since partner searches in more capital intense industries are likely to cost more, the high cost of such searches is likely to reduce the cost responsiveness of those sectors. To test this idea, Table 5 adds new regressors that interact industry capital intensity with the own and competitor cost measures. ${ }^{23}$ The coefficients on the cost interactions for 1980-1990 indicate that all cost responses are attenuated in more capital intense industries. The results imply that the cost response for overseas assembly in the least capital intense industries is 30 percent larger than cost responses for the most capital intense industries. ${ }^{24}$ The results for 1991-2000 also imply that own cost responses were smaller in more capital intense industries, though the interaction term is not statistically significant.

Market thickness in partners is another element that may influence the relative attractiveness of searching for partners in new countries. ${ }^{25}$ One way of thinking about market thickness in the context of OAP imports, is to examine how many countries produced products in a particular 4-digit industry during the period examined, and to see whether the effects of cost changes were more or less pronounced for industries that were characterized by "thick markets" for partners. I do this by adding regressors that interact the cost terms with counts of potential suppliers, where potential competitors are defined

\footnotetext{
${ }^{23}$ While it would be desirable to use capital intensity measures that characterize the capital intensity of the foreign assembly operations, no such measures exist. The average capital intensity for the U.S. industry during the sample period is used instead. If U.S. industries achieve high capital intensity by outsourcing low intensity activities, the interaction terms will underestimate the effect of capital intensity on cost responses.

${ }_{24}$ The implied cost response for firms whose capital intensity is in 10th percentile is -.202, while the cost response for those in the 90th percentile is -.155 .

${ }^{25}$ Market thickness facilitates outsourcing in both McLaren's (2000) and Grossman and Helpman's (2002b) models. In McLaren's model which has multiple equilibria, market thickness increases outsourcing through "arm's length" arrangements. In Grossman and Helpman the degree of outsourcing is influenced by firm's likelihood of finding a suitable outsourcing partner, which is enhanced by market thickness. In both models, the degree of market thickness is endogenous.
} 
as in Table 1. In these regressions I expect that the detrimental effect of own cost increases, and the beneficial effect of competitor cost increases will be magnified when there are more competitors. The results displayed in the third and fourth columns of Table 5 support this view. The results for1980 to 1990 imply that outsourcing combinations that were in the bottom 10th percentile, as defined by competition, had an own cost effect that was only sixty percent as large the own cost effect for outsourcing combinations in the 90 th $^{\text {percentile. }}{ }^{26}$

\section{Robustness Checks}

To investigate the robustness of the results, the regressions were performed on sub-groups of the data. The first set of results is performed for the 2-digit SIC industries that were the most frequent suppliers of the OAP program - Textiles and Apparel in SIC 23, Non-Electrical Machinery in SIC 35, and Electrical Machinery in SIC 36. These results are contained in Tables 6 and 7, and are notable in echoing the cost findings from the full data set. The coefficients on competitor costs for the Machinery and Electrical machinery industries, which are thought to be especially footloose, are particularly large. In contrast, the fact that the competitor cost coefficient is smaller for the Textile and Apparel industry may reflect rigidities that relate to the quotas imposed by the multi fibre agreement rather than a small response to competitor costs.

As a further check on the robustness of the results, the regression was run separately for countries that were the most frequent suppliers of the OAP program. The cost coefficients from these regressions are reported in Table 8 . In the country sub-

\footnotetext{
${ }^{26}$ The implied own cost coefficient for the 10th percentile was -.131 , and -.223 for the 90 th percentile.
} 
samples, the coefficient on own cost is generally negative as expected, though many are not statistically significant. In contrast, the results for competitor cost are almost all positive and significant, confirming the benefit OAP suppliers experience when their competitors' costs rise. The magnitudes of the competitor cost coefficients by country appear to reflect the industry mix of the products they provide. For example, the competitor cost response is always high for Singapore, a country that produced many items in the machinery categories. The cross-country variation in competitor cost coefficients also appears to have a weak correlation with market shares. Most notably, the response to competitor costs is smaller for Canada and Mexico, which generally supply a higher than average share of the market. However, when I tested whether market shares had a direct effect of cost responsiveness, by adding interactions for own and competitor cost with (average share) $)_{\mathrm{c}}$, the estimated coefficients on the interaction terms were not significant. Finally I tested whether the implementation of the CanadaUS Free Trade Agreement in 1989, or the implementation of the North American Free Trade Agreement in 1994 affected Canada or Mexico's country shares by adding a FTA dummy for the years where a free trade agreements was in force. However, explicit treatment of the free trade years does not generally change the cost results for Canada or Mexico.

\subsection{Conclusion}

This paper analyzes the cost responsiveness of U.S. OAP outsourcing imports between 1980 and 2000. The results demonstrate that a country's share of OAP outsourcing grows when its own costs fall, or when its competitors' costs rise. For the 
1990 's, the results imply that a 10 percent increase in a country's costs would reduce its share by $0.8 \%$, which is relatively large compared with the average share which was 5.6\%. One implication of the results is that tariff reductions offered by U.S. trade preference programs, such as the Andean Trade Pact, the US-Caribbean Basin Trade Partnership Act, or the African Growth and Opportunity Act, have probably elevated the share of U.S. trade originating from partner countries.

The magnitude of cost responses varies on a number of interesting dimensions. First, cost changes are found to exert a much larger influence on the OAP import shares of developing countries than on the OAP import shares of developed countries. In addition, cost responses of less capital intense industries are generally larger than those for more capital intense sectors. In both cases, the differential responses by country or industry are consistent with the predictions of outsourcing models that feature fixed costs of search or product development. Nonetheless, the general own and competitor cost results seem to apply broadly across countries and industries.

Since the OAP program facilitates the use of U.S. materials and components in overseas assembly, it is important to remember that it captures only one element of U.S. outsourcing activities. In particular, if OAP assembly tasks are generally less complex, and therefore more easily matched and coordinated than are other types of outsourcing operations, then the frictions emphasized by Grossman and Helpman (2004) may inhibit outsourcing flexibility in other sectors to a greater degree than is found in the OAP context. Further research focusing other outsourcing venues would help complete the picture. 
9802/OAP Usage, 1971-2000

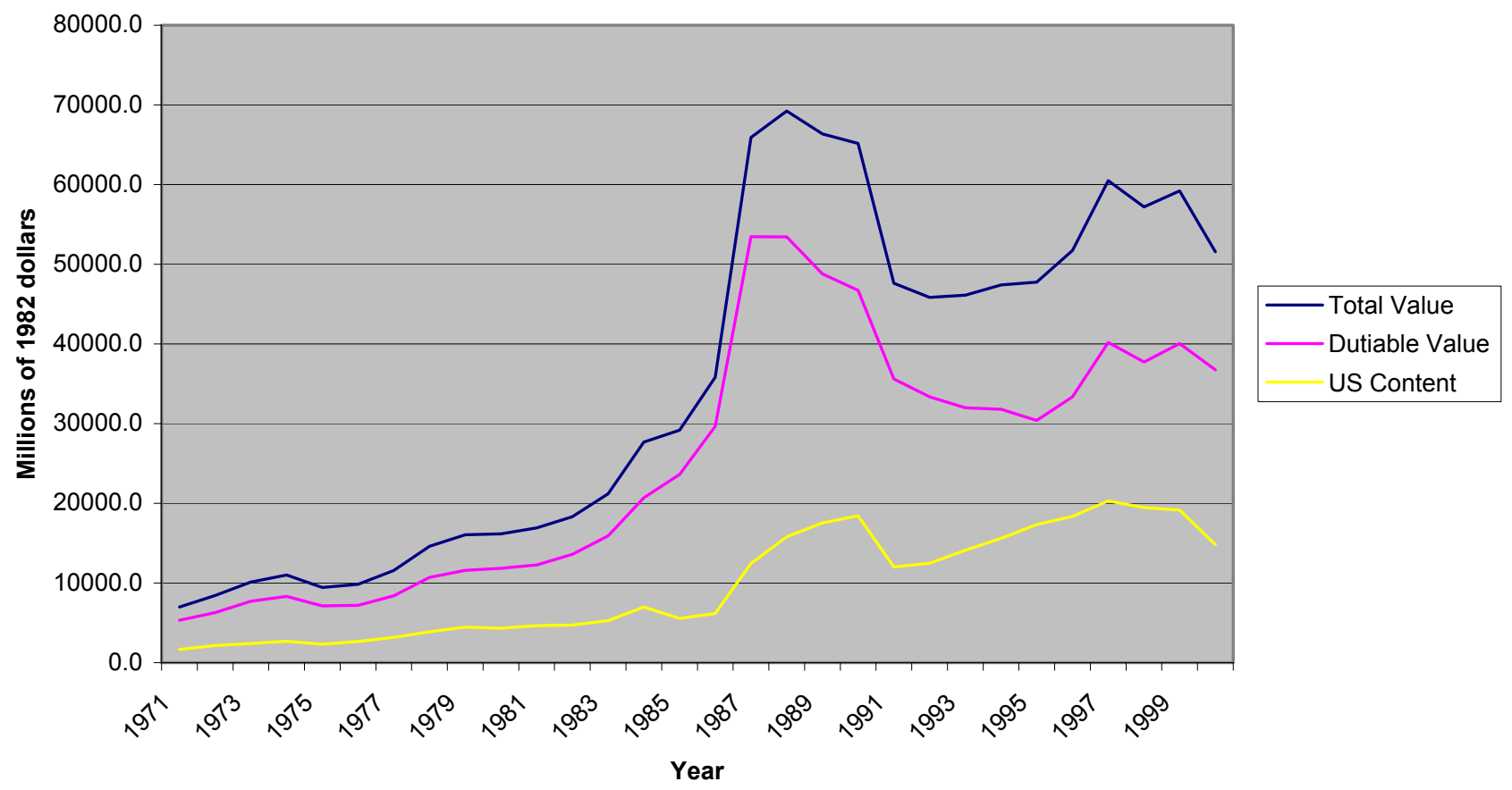




\begin{tabular}{|c|c|c|c|c|c|c|}
\hline & & $1980-1990$ & & & $1991-2000$ & \\
\hline $\begin{array}{l}\text { 2-Digit } \\
\text { SIC Industry }\end{array}$ & $\begin{array}{c}\text { Number } \\
\text { of Positive } \\
\text { Country- } \\
\text { Industry } \\
\text { Obs. }\end{array}$ & $\begin{array}{c}\text { Number } \\
\text { of 4-digit } \\
\text { SIC } \\
\text { Industries }\end{array}$ & $\begin{array}{l}\text { Competing } \\
\text { Country } \\
\text { Suppliers }\end{array}$ & $\begin{array}{c}\text { Number } \\
\text { of } \\
\text { Positive } \\
\text { Country- } \\
\text { Industry } \\
\text { Obs. }\end{array}$ & $\begin{array}{c}\text { Number } \\
\text { of 4-digit } \\
\text { SIC } \\
\text { Industries }\end{array}$ & $\begin{array}{c}\text { Competing } \\
\text { Country } \\
\text { Suppliers }\end{array}$ \\
\hline 20 Food Products & 84 & 31 & 3 & 98 & 24 & 3 \\
\hline 22 Textile Products & 224 & 28 & 14 & 656 & 15 & 13 \\
\hline 23 Apparel & 3,045 & 33 & 41 & 5,483 & 27 & 39 \\
\hline $\begin{array}{l}24 \text { Wood Products, } \\
\text { excluding Furniture }\end{array}$ & 307 & 17 & 9 & 140 & 16 & 3 \\
\hline 25 Furniture & 413 & 13 & 25 & 94 & 7 & 5 \\
\hline 26 Paper Products & 403 & 15 & 14 & 303 & 14 & 7 \\
\hline $\begin{array}{l}\text { 27 Printing \& } \\
\text { Publishing }\end{array}$ & 117 & 14 & 7 & 174 & 8 & 6 \\
\hline \begin{tabular}{|l|}
28 Chemical \\
Products \\
\end{tabular} & 176 & 25 & 6 & 328 & 22 & 5 \\
\hline $\begin{array}{l}29 \text { Petroleum \& } \\
\text { Related Products }\end{array}$ & 18 & 5 & 6 & 11 & 3 & 2 \\
\hline $\begin{array}{l}30 \text { Rubber \& Plastic } \\
\text { Products }\end{array}$ & 385 & 6 & 2 & 651 & 10 & 16 \\
\hline 31 Leather Products & 508 & 11 & 23 & 1,018 & 11 & 23 \\
\hline \begin{tabular}{|l|}
32 Stone, Clay \& \\
Glass Products \\
\end{tabular} & 197 & 22 & 6 & 341 & 18 & 7 \\
\hline $\begin{array}{l}33 \text { Primary Metal } \\
\text { Products }\end{array}$ & 676 & 25 & 17 & 596 & 14 & 11 \\
\hline $\begin{array}{l}\text { 34 Fabricated Metal } \\
\text { Products }\end{array}$ & 938 & 32 & 14 & 970 & 29 & 9 \\
\hline $\begin{array}{l}35 \text { Non-Electrical } \\
\text { Machinery }\end{array}$ & 2,773 & 44 & 21 & 2,563 & 47 & $\overline{15}$ \\
\hline \begin{tabular}{|l|}
36 Electrical \\
Machinery \\
\end{tabular} & 3,424 & 39 & 30 & 3,549 & 35 & 23 \\
\hline $\begin{array}{l}37 \text { Transportation } \\
\text { Equipment }\end{array}$ & 1,001 & 17 & 20 & 841 & 15 & 13 \\
\hline $\begin{array}{l}38 \text { Measuring, } \\
\text { Analyzing and } \\
\text { Controlling } \\
\text { Instruments }\end{array}$ & 1,248 & 13 & 32 & 1,523 & 16 & 23 \\
\hline $\begin{array}{l}39 \text { Miscellaneous } \\
\text { Manufacturing }\end{array}$ & 725 & 19 & 18 & 1,188 & 17 & 17 \\
\hline
\end{tabular}

Notes: Competing Country Suppliers is defined as the average number of competitors for the 4digit industries contained in a 2-digit industry. 


\begin{tabular}{|c|c|c|c|c|c|c|}
\hline \multicolumn{7}{|c|}{ TABLE 2: COUNTRY COSTS AND OUTSOURCING CHOICES } \\
\hline \multicolumn{7}{|c|}{ Dependent Variable: Country Share } \\
\hline & \multicolumn{2}{|c|}{ TOBIT } & \multicolumn{2}{|c|}{ RE TOBIT } & \multicolumn{2}{|c|}{ RE TOBIT } \\
\hline & $(1)$ & $(2)$ & $(3)$ & $(4)$ & $(5)$ & $(6)$ \\
\hline Sample Years & $\begin{array}{l}1980- \\
1990\end{array}$ & $\begin{array}{l}1991- \\
2000\end{array}$ & $\begin{array}{l}1980- \\
1990\end{array}$ & $\begin{array}{l}1991- \\
2000\end{array}$ & $\begin{array}{c}1980- \\
1990\end{array}$ & $\begin{array}{l}1991- \\
2000\end{array}$ \\
\hline & & & & & & \\
\hline Own $\operatorname{Cost}_{\mathrm{t}-2}$ & $\begin{array}{l}-.133 \\
(.006)\end{array}$ & $\begin{array}{l}-.038 \\
(.008)\end{array}$ & $\begin{array}{l}-.180 \\
(.011)\end{array}$ & $\begin{array}{l}-.088 \\
(.012)\end{array}$ & $\begin{array}{l}-.192 \\
(.011)\end{array}$ & $\begin{array}{l}-.110 \\
(.011)\end{array}$ \\
\hline Competitor Cost $_{\mathrm{t}-2}$ & $\begin{array}{c}.290 \\
(.003)\end{array}$ & $\begin{array}{c}.271 \\
(.002)\end{array}$ & $\begin{array}{l}.169 \\
(.008)\end{array}$ & $\begin{array}{c}.299 \\
(.007)\end{array}$ & $\begin{array}{c}.171 \\
(.008)\end{array}$ & $\begin{array}{c}.303 \\
(.007)\end{array}$ \\
\hline $1 /(\# \text { of Competitors })_{\mathrm{ci}}$ & $\begin{array}{l}-.227 \\
(.040)\end{array}$ & $\begin{array}{l}.110 \\
(.026)\end{array}$ & $\begin{array}{l}2.254 \\
(.096)\end{array}$ & $\begin{array}{l}1.479 \\
(.051)\end{array}$ & $\begin{array}{l}2.295 \\
(.096) \\
\end{array}$ & $\begin{array}{l}1.509 \\
(.050)\end{array}$ \\
\hline GDP & $\begin{array}{l}-.001 \\
(.008)\end{array}$ & $\begin{array}{l}-.201 \\
(.013)\end{array}$ & $\begin{array}{l}-.022 \\
(.010)\end{array}$ & $\begin{array}{l}.016 \\
(.009)\end{array}$ & & \\
\hline GDP/Capita & $\begin{array}{c}.001 \\
(.003) \\
\end{array}$ & $\begin{array}{l}-.030 \\
(.003) \\
\end{array}$ & $\begin{array}{l}-.015 \\
(.033) \\
\end{array}$ & $\begin{array}{l}-.011 \\
(.003) \\
\end{array}$ & & \\
\hline Distance & & & $\begin{array}{l}-.132 \\
(.006)\end{array}$ & $\begin{array}{l}-.036 \\
(.005)\end{array}$ & $\begin{array}{l}-.130 \\
(.006)\end{array}$ & $\begin{array}{l}-.036 \\
(.004)\end{array}$ \\
\hline $\begin{array}{l}\text { Capital Intensity* } \\
\text { Developed Country }\end{array}$ & $\begin{array}{l}.028 \\
(.005) \\
\end{array}$ & $\begin{array}{l}.034 \\
(.005)\end{array}$ & $\begin{array}{l}.046 \\
(.013) \\
\end{array}$ & $\begin{array}{l}-.006 \\
(.010) \\
\end{array}$ & $\begin{array}{l}.045 \\
(.013) \\
\end{array}$ & $\begin{array}{l}-.006 \\
(.010) \\
\end{array}$ \\
\hline $\begin{array}{l}\text { Capital Intensity* } \\
\text { Developing Country }\end{array}$ & $\begin{array}{l}-.070 \\
(.005)\end{array}$ & $\begin{array}{l}-.048 \\
(.005)\end{array}$ & $\begin{array}{l}-.012 \\
(.011)\end{array}$ & $\begin{array}{l}-.053 \\
(.008)\end{array}$ & $\begin{array}{l}-.013 \\
(.011) \\
\end{array}$ & $\begin{array}{l}-.053 \\
(.008)\end{array}$ \\
\hline Education & & & $\begin{array}{l}-.091 \\
(.016)\end{array}$ & $\begin{array}{l}-.071 \\
(.013)\end{array}$ & $\begin{array}{l}-.139 \\
(.010)\end{array}$ & $\begin{array}{l}-.102 \\
(.010)\end{array}$ \\
\hline OECD Dummy & & & $\begin{array}{c}.368 \\
(.017) \\
\end{array}$ & $\begin{array}{l}.220 \\
(.016)\end{array}$ & $\begin{array}{c}.369 \\
(.017) \\
\end{array}$ & $\begin{array}{c}.223 \\
(.016)\end{array}$ \\
\hline Country Dummies & Yes & Yes & No & No & No & No \\
\hline Industry Dummies & Yes & Yes & No & No & No & No \\
\hline Log Likelihood & $-7,547$ & $-8,346$ & $-17,593$ & $-14,545$ & $-17,612$ & $-14,830$ \\
\hline Observations & 43,790 & 40,269 & 43,790 & 40,269 & 43,790 & 40,269 \\
\hline Uncensored Observations & 15,608 & 17,155 & 15,608 & 17,155 & 15,608 & 17,155 \\
\hline Left-censored Observations & 26,513 & 21,576 & 26,513 & 21,576 & 26,513 & 21,576 \\
\hline Right-censored Obs & 1,669 & 1,538 & 1,669 & 1,538 & 1,669 & 1,538 \\
\hline
\end{tabular}

Notes: Standard errors in ( ). 


\begin{tabular}{|c|c|c|c|c|}
\hline \multicolumn{5}{|c|}{$\begin{array}{l}\text { TABLE 3: OUTSOURCING CHOICES BY DEVELOPMENT -- 1980-1990 } \\
\end{array}$} \\
\hline \multicolumn{5}{|c|}{ Dependent Variable: Country Share } \\
\hline & \multicolumn{2}{|c|}{ OECD } & \multicolumn{2}{|c|}{ EDUCATION } \\
\hline COUNTRY GROUP & OECD & NON-OECD & $>6 \mathrm{YRS}$ & $<6 \mathrm{YRS}$ \\
\hline & & & & \\
\hline Own Cost $t_{t-2}$ & $\begin{array}{l}-.106 \\
(.018)\end{array}$ & $\begin{array}{l}-.298 \\
(.016)\end{array}$ & $\begin{array}{l}-.033 \\
(.050)\end{array}$ & $\begin{array}{l}-.139 \\
(.012)\end{array}$ \\
\hline Competitor Cost $t_{t-2}$ & $\begin{array}{l}.152 \\
(.014)\end{array}$ & $\begin{array}{l}.203 \\
(.012) \\
\end{array}$ & $\begin{array}{c}.027 \\
(.106) \\
\end{array}$ & $\begin{array}{l}.150 \\
(.010)\end{array}$ \\
\hline 1/(\# Dev'd Competitors $)_{\mathrm{ci}}$ & $\begin{array}{l}1.362 \\
(.119)\end{array}$ & & $\begin{array}{l}-.537 \\
(.011)\end{array}$ & \\
\hline 1/(\# Dev'ing Competitors) $)_{\mathrm{ci}}$ & & $\begin{array}{c}.863 \\
(.053)\end{array}$ & & $\begin{array}{c}.050 \\
(.022)\end{array}$ \\
\hline GDP & $\begin{array}{l}.454 \\
(.044)\end{array}$ & $\begin{array}{l}-.018 \\
(.012)\end{array}$ & $\begin{array}{l}-.096 \\
(.117)\end{array}$ & $\begin{array}{c}.052 \\
(.011)\end{array}$ \\
\hline GDP/Capita & $\begin{array}{l}-.015 \\
(.006)\end{array}$ & $\begin{array}{l}-0.011 \\
(.004)\end{array}$ & $\begin{array}{l}.124 \\
(.026)\end{array}$ & $\begin{array}{l}-.042 \\
(.004)\end{array}$ \\
\hline Distance & $\begin{array}{l}-.071 \\
(.008)\end{array}$ & $\begin{array}{l}-.166 \\
(.009)\end{array}$ & $\begin{array}{c}.070 \\
(.048)\end{array}$ & $\begin{array}{l}-.122 \\
(.006)\end{array}$ \\
\hline Capital Intensity & $\begin{array}{c}.075 \\
(.013)\end{array}$ & $\begin{array}{l}-.005 \\
(.011)\end{array}$ & $\begin{array}{c}.335 \\
(.056) \\
\end{array}$ & $\begin{array}{l}.057 \\
(.009) \\
\end{array}$ \\
\hline Education & $\begin{array}{l}-.015 \\
(.042) \\
\end{array}$ & $\begin{array}{c}-.124 \\
(.018) \\
\end{array}$ & $\begin{array}{l}-.059 \\
(.082)\end{array}$ & $\begin{array}{c}.250 \\
(.023)\end{array}$ \\
\hline OECD Dummy & \multicolumn{2}{|c|}{$\begin{array}{l}-3.545 \\
(.213)\end{array}$} & \multicolumn{2}{|c|}{$\begin{array}{c}.047 \\
(.013)\end{array}$} \\
\hline Log Likelihood & \multicolumn{2}{|c|}{$-17,501$} & \multicolumn{2}{|c|}{$-17,047$} \\
\hline Observations & \multicolumn{2}{|c|}{43,790} & \multicolumn{2}{|c|}{43,790} \\
\hline Uncensored Observations & \multicolumn{2}{|c|}{15,608} & \multicolumn{2}{|c|}{15,608} \\
\hline Left-censored Observations & \multicolumn{2}{|c|}{26,513} & \multicolumn{2}{|c|}{26,513} \\
\hline Right-censored Obs & \multicolumn{2}{|c|}{1,669} & \multicolumn{2}{|c|}{1,669} \\
\hline
\end{tabular}

Notes: Standard errors in ( ). Regressions estimated by random effects Tobit. 


\begin{tabular}{|c|c|c|c|c|}
\hline \multicolumn{5}{|c|}{$\begin{array}{l}\text { TABLE 4: OUTSOURCING CHOICES BY DEVELOPMENT - 1991-2000 } \\
\end{array}$} \\
\hline \multicolumn{5}{|c|}{ Dependent Variable: Country Share } \\
\hline & \multicolumn{2}{|c|}{ OECD } & \multicolumn{2}{|c|}{ EDUCATION } \\
\hline COUNTRY GROUP & OECD & NON-OECD & $>6 \mathrm{YRS}$ & $<6 \mathrm{YRS}$ \\
\hline & & & & \\
\hline Own $\operatorname{Cost}_{\mathrm{t}-2}$ & $\begin{array}{l}-.089 \\
(.028)\end{array}$ & $\begin{array}{l}.139 \\
(.015)\end{array}$ & $\begin{array}{l}-.053 \\
(.042)\end{array}$ & $\begin{array}{l}-.058 \\
(.013)\end{array}$ \\
\hline Competitor Cost $t_{t-2}$ & $\begin{array}{l}-.139 \\
(.015)\end{array}$ & $\begin{array}{l}.353 \\
(.009) \\
\end{array}$ & $\begin{array}{c}.662 \\
(.289) \\
\end{array}$ & $\begin{array}{l}.318 \\
(.006)\end{array}$ \\
\hline 1/(\# Dev'd Competitors $)_{\mathrm{ci}}$ & $\begin{array}{c}.945 \\
(.074)\end{array}$ & & $\begin{array}{l}-.503 \\
(.009)\end{array}$ & \\
\hline 1/(\# Dev'ing Competitors $)_{\mathrm{ci}}$ & & $\begin{array}{c}.823 \\
(.048)\end{array}$ & & $\begin{array}{l}-.013 \\
(.015)\end{array}$ \\
\hline GDP & $\begin{array}{l}.145 \\
(.037)\end{array}$ & $\begin{array}{l}-.029 \\
(.009)\end{array}$ & $\begin{array}{c}.124 \\
(.117)\end{array}$ & $\begin{array}{c}.031 \\
(.011)\end{array}$ \\
\hline GDP/Capita & $\begin{array}{l}-.027 \\
(.005)\end{array}$ & $\begin{array}{l}-.0001 \\
(.003)\end{array}$ & $\begin{array}{l}-.003 \\
(.022)\end{array}$ & $\begin{array}{l}-.023 \\
(.003)\end{array}$ \\
\hline Distance & $\begin{array}{l}-.025 \\
(.008)\end{array}$ & $\begin{array}{l}-.056 \\
(.009)\end{array}$ & $\begin{array}{l}-.042 \\
(.052)\end{array}$ & $\begin{array}{l}-.011 \\
(.005)\end{array}$ \\
\hline Capital Intensity & $\begin{array}{c}.028 \\
(.011)\end{array}$ & $\begin{array}{l}-.056 \\
(.008)\end{array}$ & $\begin{array}{l}-.016 \\
(.048)\end{array}$ & $\begin{array}{c}.008 \\
(.008)\end{array}$ \\
\hline Education & $\begin{array}{l}-.063 \\
(.035)\end{array}$ & $\begin{array}{l}-.061 \\
(.015)\end{array}$ & $\begin{array}{l}-.026 \\
(.087)\end{array}$ & $\begin{array}{l}.306 \\
(.019) \\
\end{array}$ \\
\hline OECD Dummy & \multicolumn{2}{|c|}{$\begin{array}{l}-1.048 \\
(.188)\end{array}$} & \multicolumn{2}{|c|}{$\begin{array}{l}-.068 \\
(.012)\end{array}$} \\
\hline Log Likelihood & \multicolumn{2}{|c|}{$-14,677$} & \multicolumn{2}{|c|}{$-12,735$} \\
\hline Observations & \multicolumn{2}{|c|}{40,269} & \multicolumn{2}{|c|}{40,269} \\
\hline Uncensored Observations & \multicolumn{2}{|c|}{17,155} & \multicolumn{2}{|c|}{17,155} \\
\hline Left-censored Observations & \multicolumn{2}{|c|}{21,576} & \multicolumn{2}{|c|}{21,576} \\
\hline Right-censored Obs & \multicolumn{2}{|c|}{1,538} & \multicolumn{2}{|c|}{1,538} \\
\hline
\end{tabular}

Notes: Standard errors in ( ). Regressions estimated by random effects Tobit. 


\begin{tabular}{|c|c|c|c|c|}
\hline \multicolumn{5}{|c|}{$\begin{array}{l}\text { TABLE 5: INDUSTRY CHARACTERISTICS AND OUTSOURCING COST } \\
\text { RESPONSES }\end{array}$} \\
\hline \multicolumn{5}{|c|}{ Dependent Variable: Country Share } \\
\hline & \multicolumn{2}{|c|}{ CAPITAL-INTENSITY } & \multicolumn{2}{|c|}{ COMPETITORS } \\
\hline Years & $1980-1990$ & $1991-2000$ & $1980-1990$ & $1991-2000$ \\
\hline Own Cost ${ }_{t-2}$ & $\begin{array}{l}-.221 \\
(.013)\end{array}$ & $\begin{array}{l}-.091 \\
(.013)\end{array}$ & $\begin{array}{l}-.111 \\
(.013)\end{array}$ & $\begin{array}{l}.0004 \\
(.0119)\end{array}$ \\
\hline $\begin{array}{l}\text { Own Cost } \text { t-2 }{ }^{*} \\
\text { ( Capital Intensity) }\end{array}$ & $\begin{array}{c}.094 \\
(.014)\end{array}$ & $\begin{array}{c}.012 \\
(.016)\end{array}$ & & \\
\hline $\begin{array}{l}\text { Own Cost } \text { t-2 }^{*} \\
\text { (\# of Competitors) }\end{array}$ & & & $\begin{array}{c}-.002 \\
(.0002)\end{array}$ & $\begin{array}{c}-.003 \\
(.0001) \\
\end{array}$ \\
\hline Competitor Cost $_{t-2}$ & $\begin{array}{c}.251 \\
(.014)\end{array}$ & $\begin{array}{c}.283 \\
(.014)\end{array}$ & $\begin{array}{c}.032 \\
(.012)\end{array}$ & $\begin{array}{c}.173 \\
(.009)\end{array}$ \\
\hline $\begin{array}{l}\text { Competitor Cost }{ }_{\mathrm{t}-2} * \\
\text { (Capital Intensity) }\end{array}$ & $\begin{array}{l}-.160 \\
(.024)\end{array}$ & $\begin{array}{c}.042 \\
(.029)\end{array}$ & & \\
\hline $\begin{array}{l}\text { Competitor Cost }{ }_{\mathrm{t}-2}{ }^{*} \\
\text { (\# of Competitors) }\end{array}$ & & & $\begin{array}{c}.009 \\
(.0006)\end{array}$ & $\begin{array}{c}.010 \\
(.0004)\end{array}$ \\
\hline $1 /(\#$ of Competitors) & $\begin{array}{l}2.234 \\
(.094) \\
\end{array}$ & $\begin{array}{l}1.483 \\
(.051) \\
\end{array}$ & $\begin{array}{l}3.066 \\
(.103) \\
\end{array}$ & $\begin{array}{l}2.171 \\
(.059) \\
\end{array}$ \\
\hline GDP & $\begin{array}{l}-.024 \\
(.010)\end{array}$ & $\begin{array}{l}-.016 \\
(.009)\end{array}$ & $\begin{array}{l}-.032 \\
(.011)\end{array}$ & $\begin{array}{l}-.012 \\
(.009)\end{array}$ \\
\hline GDP/Capita & $\begin{array}{l}-.014 \\
(.003)\end{array}$ & $\begin{array}{l}-.011 \\
(.003)\end{array}$ & $\begin{array}{l}-.012 \\
(.004)\end{array}$ & $\begin{array}{l}-.010 \\
(.003)\end{array}$ \\
\hline Distance & $\begin{array}{l}-.130 \\
(.006)\end{array}$ & $\begin{array}{l}-.036 \\
(.005)\end{array}$ & $\begin{array}{l}-.126 \\
(.005)\end{array}$ & $\begin{array}{l}-.035 \\
(.004)\end{array}$ \\
\hline $\begin{array}{l}\text { Capital Intensity* } \\
\text { Developed Country }\end{array}$ & $\begin{array}{l}-.036 \\
(.026)\end{array}$ & $\begin{array}{l}-.052 \\
(.022)\end{array}$ & $\begin{array}{c}.052 \\
(.012)\end{array}$ & $\begin{array}{c}.016 \\
(.010)\end{array}$ \\
\hline $\begin{array}{l}\text { Capital Intensity* } \\
\text { Developing Country }\end{array}$ & $\begin{array}{l}-.091 \\
(.023)\end{array}$ & $\begin{array}{l}-.092 \\
(.019)\end{array}$ & $\begin{array}{c}.003 \\
(.012)\end{array}$ & $\begin{array}{l}-.009 \\
(.008)\end{array}$ \\
\hline Education & $\begin{array}{l}-.085 \\
(.016)\end{array}$ & $\begin{array}{l}-.071 \\
(.013)\end{array}$ & $\begin{array}{l}-.066 \\
(.016)\end{array}$ & $\begin{array}{l}-.054 \\
(.013)\end{array}$ \\
\hline OECD Dummy & $\begin{array}{l}.366 \\
(.017)\end{array}$ & $\begin{array}{l}.213 \\
(.017)\end{array}$ & $\begin{array}{c}.361 \\
(.017)\end{array}$ & $\begin{array}{l}.181 \\
(.015)\end{array}$ \\
\hline Log Likelihood & $-17,568$ & $-14,541$ & $-17,460$ & $-14,298$ \\
\hline Observations & 43,790 & 40,269 & 43,790 & 40,269 \\
\hline Uncensored Observations & 15,608 & 17,155 & 15,608 & 17,155 \\
\hline Left-censored Observations & 26,513 & 21,576 & 26,513 & 21,576 \\
\hline Right-censored Obs & 1,669 & 1,538 & 1,669 & 1,538 \\
\hline
\end{tabular}

Notes: Standard errors in ( ). Regressions estimated by random effects Tobit. 


\begin{tabular}{|c|c|c|c|c|c|c|}
\hline \multicolumn{7}{|c|}{ TABLE 6: OUTSOURCING CHOICES BY INDUSTRY - 1980-1990 } \\
\hline \multicolumn{7}{|c|}{ Dependent Variable: Country Share } \\
\hline \multirow[b]{2}{*}{ COUNTRY GROUP } & \multicolumn{2}{|c|}{$\begin{array}{c}\text { SIC 23 } \\
\text { TEXTILES \& } \\
\text { APPAREL }\end{array}$} & \multicolumn{2}{|c|}{$\begin{array}{c}\text { SIC 35 } \\
\text { NON- } \\
\text { ELECTRICAL } \\
\text { MACHINERY }\end{array}$} & \multicolumn{2}{|c|}{$\begin{array}{c}\text { SIC 36 } \\
\text { ELECTRICAL } \\
\text { MACHINERY }\end{array}$} \\
\hline & OECD & $\begin{array}{l}\text { NON- } \\
\text { OECD } \\
\end{array}$ & OECD & $\begin{array}{l}\text { NON- } \\
\text { OECD }\end{array}$ & OECD & $\begin{array}{l}\text { NON- } \\
\text { OECD }\end{array}$ \\
\hline & & & & & & \\
\hline Own Cost ${ }_{t-2}$ & $\begin{array}{l}-.159 \\
(.037) \\
\end{array}$ & $\begin{array}{l}-.150 \\
(.017) \\
\end{array}$ & $\begin{array}{l}-.102 \\
(.017)\end{array}$ & $\begin{array}{l}-.215 \\
(.015) \\
\end{array}$ & $\begin{array}{c}-.030 \\
(.021) \\
\end{array}$ & $\begin{array}{c}-.204 \\
(.019) \\
\end{array}$ \\
\hline Competitor Cost $\mathrm{t}_{\mathrm{t}-2}$ & $\begin{array}{l}-.055 \\
(.039)\end{array}$ & $\begin{array}{c}.212 \\
(.020)\end{array}$ & $\begin{array}{c}.314 \\
(.011)\end{array}$ & $\begin{array}{c}.777 \\
(.035)\end{array}$ & $\begin{array}{c}.372 \\
(.029) \\
\end{array}$ & $\begin{array}{r}.536 \\
(.016) \\
\end{array}$ \\
\hline 1/(\# Dev'd Competitors) & $\begin{array}{l}.0004 \\
(.240)\end{array}$ & & $\begin{array}{c}-1.056 \\
(.128)\end{array}$ & & $\begin{array}{l}-.094 \\
(.241)\end{array}$ & \\
\hline 1/(\# Dev'ing Competitors) & & $\begin{array}{l}2.789 \\
(.334)\end{array}$ & & $\begin{array}{l}-.111 \\
(.060)\end{array}$ & & $\begin{array}{l}-.303 \\
(.130) \\
\end{array}$ \\
\hline GDP & $\begin{array}{c}.297 \\
(.054)\end{array}$ & $\begin{array}{l}-.022 \\
(.012)\end{array}$ & $\begin{array}{c}.187 \\
(.030)\end{array}$ & $\begin{array}{c}.069 \\
(.010)\end{array}$ & $\begin{array}{c}.216 \\
(.045)\end{array}$ & $\begin{array}{l}.019 \\
(.013)\end{array}$ \\
\hline GDP/Capita & $\begin{array}{l}-.005 \\
(.009)\end{array}$ & $\begin{array}{l}.0002 \\
(.004)\end{array}$ & $\begin{array}{l}-.048 \\
(.003)\end{array}$ & $\begin{array}{l}-.026 \\
(.004)\end{array}$ & $\begin{array}{l}-.013 \\
(.007)\end{array}$ & $\begin{array}{c}.002 \\
(.004)\end{array}$ \\
\hline Distance & $\begin{array}{c}.003 \\
(.013) \\
\end{array}$ & $\begin{array}{l}-.190 \\
(.010)\end{array}$ & $\begin{array}{c}-.085 \\
(.006) \\
\end{array}$ & $\begin{array}{l}-.078 \\
(.008)\end{array}$ & $\begin{array}{c}-.026 \\
(.009) \\
\end{array}$ & $\begin{array}{l}-.039 \\
(.009) \\
\end{array}$ \\
\hline Capital Intensity & $\begin{array}{l}-.033 \\
(.030)\end{array}$ & $\begin{array}{l}-.048 \\
(.017)\end{array}$ & $\begin{array}{c}.003 \\
(.010)\end{array}$ & $\begin{array}{l}-.015 \\
(.013)\end{array}$ & $\begin{array}{l}-.050 \\
(.017)\end{array}$ & $\begin{array}{l}-.025 \\
(.016)\end{array}$ \\
\hline Education & $\begin{array}{l}-.082 \\
(.053)\end{array}$ & $\begin{array}{c}.019 \\
(.018) \\
\end{array}$ & $\begin{array}{c}.121 \\
(.026) \\
\end{array}$ & $\begin{array}{l}-.144 \\
(.016)\end{array}$ & $\begin{array}{c}.039 \\
(.043) \\
\end{array}$ & $\begin{array}{l}-.068 \\
(.019) \\
\end{array}$ \\
\hline OECD Dummy & & & & & & \\
\hline Log Likelihood & & & & & & \\
\hline Observations & & & & & & \\
\hline Uncensored Observations & & & & & & \\
\hline Left-censored Observations & & & & & & \\
\hline Right-censored Obs & & & & & & \\
\hline
\end{tabular}

Notes: Standard errors in ( ). Regressions estimated by random effects Tobit. 


\begin{tabular}{|c|c|c|c|c|c|c|}
\hline \multicolumn{7}{|c|}{ TABLE 7: OUTSOURCING CHOICES BY INDUSTRY - 1991-2000 } \\
\hline \multicolumn{7}{|c|}{ Dependent Variable: Country Share } \\
\hline & \multicolumn{2}{|c|}{$\begin{array}{c}\text { SIC 23 } \\
\text { TEXTILES \& } \\
\text { APPAREL }\end{array}$} & \multicolumn{2}{|c|}{$\begin{array}{c}\text { SIC 35 } \\
\text { NON- } \\
\text { ELECTRICAL } \\
\text { MACHINERY }\end{array}$} & \multicolumn{2}{|c|}{$\begin{array}{c}\text { SIC 36 } \\
\text { ELECTRICAL } \\
\text { MACHINERY }\end{array}$} \\
\hline COUNTRY GROUP & OECD & $\begin{array}{l}\text { NON- } \\
\text { OECD }\end{array}$ & OECD & $\begin{array}{l}\text { NON- } \\
\text { OECD }\end{array}$ & OECD & $\begin{array}{l}\text { NON- } \\
\text { OECD }\end{array}$ \\
\hline & & & & & & \\
\hline Own Cost ${ }_{t-2}$ & $\begin{array}{l}-.090 \\
(.020)\end{array}$ & $\begin{array}{l}-.036 \\
(.009)\end{array}$ & $\begin{array}{c}.035 \\
(.069)\end{array}$ & $\begin{array}{l}-.250 \\
(.035\end{array}$ & $\begin{array}{l}-.092 \\
(.038)\end{array}$ & $\begin{array}{l}-.113 \\
(.021)\end{array}$ \\
\hline Competitor Cost $t-2$ & $\begin{array}{l}.189 \\
(.060)\end{array}$ & $\begin{array}{l}.321 \\
(.005)\end{array}$ & $\begin{array}{c}.410 \\
(.042) \\
\end{array}$ & $\begin{array}{c}.619 \\
(.036) \\
\end{array}$ & $\begin{array}{l}.779 \\
(.090) \\
\end{array}$ & $\begin{array}{l}.399 \\
(.009) \\
\end{array}$ \\
\hline 1/(\# Dev'd Competitors) & $\begin{array}{l}.118 \\
(.074)\end{array}$ & & $\begin{array}{c}.534 \\
(.215)\end{array}$ & & $\begin{array}{l}-.239 \\
(.161)\end{array}$ & \\
\hline 1/(\# Dev'ing Competitors) & & $\begin{array}{l}-.276 \\
(.164) \\
\end{array}$ & & $\begin{array}{l}.119 \\
(.172) \\
\end{array}$ & & $\begin{array}{r}.294 \\
(.103) \\
\end{array}$ \\
\hline GDP & $\begin{array}{c}.154 \\
(.027)\end{array}$ & $\begin{array}{c}.001 \\
(.006)\end{array}$ & $\begin{array}{c}.011 \\
(.102)\end{array}$ & $\begin{array}{l}-.031 \\
(.038)\end{array}$ & $\begin{array}{l}-.018 \\
(.051)\end{array}$ & $\begin{array}{l}-.001 \\
(.013)\end{array}$ \\
\hline GDP/Capita & $\begin{array}{l}-.013 \\
(.006)\end{array}$ & $\begin{array}{l}-.007 \\
(.002)\end{array}$ & $\begin{array}{l}-.040 \\
(.011)\end{array}$ & $\begin{array}{l}-.002 \\
(.010)\end{array}$ & $\begin{array}{l}-.023 \\
(.006)\end{array}$ & $\begin{array}{c}.004 \\
(.004)\end{array}$ \\
\hline Distance & $\begin{array}{l}.010 \\
(.005) \\
\end{array}$ & $\begin{array}{l}-.055 \\
(.005) \\
\end{array}$ & $\begin{array}{l}.-087 \\
(.018) \\
\end{array}$ & $\begin{array}{r}.059 \\
(.028) \\
\end{array}$ & $\begin{array}{l}-.0004 \\
(.009) \\
\end{array}$ & $\begin{array}{l}-.009 \\
(.010) \\
\end{array}$ \\
\hline Capital Intensity & $\begin{array}{l}-.042 \\
(.014)\end{array}$ & $\begin{array}{l}-.001 \\
(.007) \\
\end{array}$ & $\begin{array}{l}-.145 \\
(.033) \\
\end{array}$ & $\begin{array}{l}-.046 \\
(.038)\end{array}$ & $\begin{array}{l}.0001 \\
(.018)\end{array}$ & $\begin{array}{c}.049 \\
(.014) \\
\end{array}$ \\
\hline Education & $\begin{array}{l}-.071 \\
(.025) \\
\end{array}$ & $\begin{array}{c}.009 \\
(.008) \\
\end{array}$ & $\begin{array}{l}-.016 \\
(.079) \\
\end{array}$ & $\begin{array}{l}-.285 \\
(.053) \\
\end{array}$ & $\begin{array}{l}.069 \\
(.043) \\
\end{array}$ & $\begin{array}{l}-.038 \\
(.018) \\
\end{array}$ \\
\hline OECD Dummy & \multicolumn{2}{|c|}{$\begin{array}{l}-.725 \\
(.138)\end{array}$} & \multicolumn{2}{|c|}{$\begin{array}{l}-.349 \\
(.001)\end{array}$} & \multicolumn{2}{|c|}{$\begin{array}{l}-.956 \\
(.300) \\
\end{array}$} \\
\hline Log Likelihood & \multicolumn{2}{|c|}{4,072} & \multicolumn{2}{|c|}{$-2,195$} & \multicolumn{2}{|c|}{-186} \\
\hline Observations & \multicolumn{2}{|c|}{7,570} & \multicolumn{2}{|c|}{5,892} & \multicolumn{2}{|c|}{6,740} \\
\hline Uncensored Observations & \multicolumn{2}{|c|}{4,434} & \multicolumn{2}{|c|}{2,245} & \multicolumn{2}{|c|}{2,990} \\
\hline Left-censored Observations & \multicolumn{2}{|c|}{3,134} & \multicolumn{2}{|c|}{3,521} & \multicolumn{2}{|c|}{3,770} \\
\hline Right-censored Obs & \multicolumn{2}{|c|}{2} & \multicolumn{2}{|c|}{127} & \multicolumn{2}{|c|}{50} \\
\hline
\end{tabular}

Notes: Standard errors in ( ). Regressions estimated by random effects Tobit. 


\begin{tabular}{|c|c|c|c|}
\hline \multicolumn{4}{|c|}{ TABLE 8: OUTSOURCING CHOICES BY COUNTRY } \\
\hline \multicolumn{4}{|c|}{ Dependent Variable: Country Share } \\
\hline & Own Cost $_{\mathrm{t}-2}$ & Competitor Cost $t_{t-2}$ & $\begin{array}{c}\text { Uncensored } \\
\text { Observations }\end{array}$ \\
\hline \multicolumn{4}{|l|}{ 1980-1990 } \\
\hline Mexico & $.054(.060)$ & $.218(.018)$ & 1,718 \\
\hline Canada & $.115(.091)$ & $.156(.014)$ & 1,791 \\
\hline Canada* & $.095(.091)$ & $.157(.014)$ & 1,791 \\
\hline Japan & $-.156(.053)$ & $.253(.038)$ & 1,010 \\
\hline Germany & $.029(.056)$ & $.188(.037)$ & 822 \\
\hline UK & $-.195(.073)$ & $-.088(.052)$ & 830 \\
\hline Singapore & $-.298(.069)$ & $.440(.056)$ & 452 \\
\hline Philippines & $-.113(.041)$ & $.105(.064)$ & 442 \\
\hline \multicolumn{4}{|l|}{ 1991-2000 } \\
\hline Mexico & $-.046(.097)$ & $.216(.012)$ & 1,992 \\
\hline Mexico* & $.034(.098)$ & $.216(.012)$ & 1,992 \\
\hline Canada & $1.083(.127)$ & $.197(.018)$ & 1,700 \\
\hline China & $-.026(.034)$ & $.372(.075)$ & 1,147 \\
\hline Taiwan & $-.027(.118)$ & $.511(.084)$ & 997 \\
\hline Japan & $-.033(.061)$ & $.489(.053)$ & 951 \\
\hline UK & $-.264(.143)$ & $.195(.034)$ & 706 \\
\hline Germany & $-.058(.123)$ & $.499(.061)$ & 671 \\
\hline Philippines & $-.030(.028)$ & $.563(.060)$ & 488 \\
\hline Singapore & $-.254(.089)$ & $.560(.054)$ & 428 \\
\hline
\end{tabular}

Notes: Standard errors in ( ). Regressions estimated by random effects Tobit. The “*” regressions were augmented to include a FTA dummy for years when the countries had a free trade agreement with the U.S. 


\section{Data Appendix}

\section{OAP Imports}

The import data are taken from United States International Trade Commission (USITC) reports on 806/807 and 9082 imports. The data on OAP import values between 1980 and 1988 originate from information on 806/807 imports in the Tariff Schedule of the United States, while the import data for 1989 to 2000 were registered under the provisions of 9802 in the Harmonized System for the years. The data for the years 1980 to 1988 were scanned from hard copies of the trade data, while the later years were available electronically. Due to poor quality of the hard copy originals, it was not possible to include data from the years 1982 or 1988 . The data from these programs were aggregated to the 4-digit SIC industry level to facilitate comparison with U.S. industry data. Robert Feenstra's concordance at the National Bureau of Economic Research, at http://www.nber.org/data_index.html was used to categorize U.S. imports to 1972 four-digit industries, while Peter Schott's http://www.som.yale.edu/faculty/pks4/sub_international.htm concordance facilitated creation of 1987-based SIC information. The 1980-2000 panel was divided into a 1980-1990 panel which was based on 1974 4-digit SIC codes, while the data for 1991-2000 were based on 1987 4-digit industry classifications. Computing costs using equation (4) requires a measure of $\alpha_{\mathrm{us}, \text { ic }}$ which describes the fraction of inputs that are U.S.-origin. This was computed by [(Total Customs Value $\left.)_{\text {ic }}-(\text { Dutiable Value })_{i c}\right] /(\text { Total Customs Value })_{i c}$.

\section{Industry Characteristics}

Data on U.S. industry characteristics were collected from the NBER Manufacturing Database, which is available from the National Bureau of Economic Research data site, at http://www.nber.org/data_index.html, as constructed by Bartlesman, Becker and Gray. Capital intensity was measured by dividing industry capital stock variable by industry shipments, and taking the average value for the time period, 1980-1990 in the first panel, and 1991 to 1996 in the second panel, since the industry data end in 1996.

\section{Tariffs and Transportation Costs}

Transportation costs were constructed from Robert C. Feenstra's data "U.S. Imports and Exports by 4-digit SIC Industry, 1958-94" which are posted and described at http://data.econ.ucdavis.edu/international/usixd/usixd4sic.html. Tariff data for 1980-1988 were available Chris Magee's "U.S. Tariffs at the SIC Level, 1974-1988, at data.econ.ucdavis.edu/international/ustariff.html. Tariff and transportation cost data for the later panel were taken from Peter Schott's web site cited above.

Macroeconomic and Country Variables

Country price and macroeconomic information were taken from Alan Heston, Robert Summers and Bettina Aten, Penn World Table Version 6.1, Center for International Comparisons at the University of Pennsylvania (CICUP), October 2002, available at http://pwt.econ.upenn.edu/. Exchange rates were collected from were collected from the International Monetary Fund's International Financial Statistics. Distance information was collected from Jon Haveman's site, http://www.macalester.edu/research/economics/PAGE/HAVEMAN/Trade.Resources/Gravity/Dis t.txt.

\section{Education Variables}

Data on country education was collected from Barro and Lee's data, available from the National Bureau of Economic Research, at http://www.nber.org/data_index.html.

The regressions are based on the log form of all continuous independent variables. 


\section{References}

Baldwin, Richard E, 1988. "Hysteresis in Import Prices: The Beachhead Effect." American Economic Review, September, 78(4):773-85.

Baldwin, Richard E. and Krugman, Paul R, 1989. "Persistent Trade Effects of Large Exchange Rate Shocks." Quarterly Journal of Economic, November, 104(4): 635-54.

Bernard, Andrew B., Jensen, J. Bradford, 2004. "Firm Structure, Multinationals and Manufacturing Plant Deaths," previously NBER Working Paper 9026, "The Deaths of Manufacturing Plants".

Bernard, Andrew B., Jensen, J. Bradford, and Peter K. Schott, 2002. "Survival of the Best Fit: Competition from Low Wage countries and the (Uneven) Growth of US Manufacturing Plants, NBER Working Paper, 9170, September.

Besedes, Tibor and Thomas J. Prusa, 2003. "On the Duration of Trade." NBER Working Paper, 9936, September.

Deardorff, Alan V., 2001. "Fragmentation across Cones," in Arndt, Sven W. and Henryk Kierzkowski (eds.), Fragmentation: New Production Patterns in the World Economy, Oxford:Oxford University Press, 35-51.

Dixit, Avinash, 1989. "Hysteresis, Import Penetration, and Exchange Rate Pass-Through." Quarterly Journal of Economics, May, 104(2): 205-28.

Evans, Carolyn L. and James Harrigan, 2003. “Distance, Time and Specialization,” NBER Working Paper 9729, May.

Feenstra, Robert C., 1998. "Integration of Trade and Disintegration of Production in the Global Economy," Journal of Economic Perspectives, 12(4): 31-50.

Feenstra, Robert C., and Gordon H. Hanson, and Deborah L. Swenson, 2000. "Offshore Assembly from the United States: Production Characteristics of the 9802 Program," in Robert C. Feenstra, editor, The Impact of International Trade on Wages, Chicago, IL: University of Chicago Press, 85-122.

Feenstra, Robert C., John Romalis, and Peter K. Schott, 2002. "U.S. Imports, Exports, and Tariff Data, 1989-2001. NBER Working Paper \#9387, December.

Goldberg, Pinelopi and Michael M. Knetter,1999. "Measuring the Intensity of Competition in Export Markets" Journal of International Economics, 47:27-60.

Gorg, Holger, 2000. "Fragmentation and trade: US inward processing trade in the EU." Weltwirtschaftliches Archiv - Review of World Economics, V136(N3):403-422.

Greenhut, M.L. and H. Ohta, 1979. "Vertical Integrations of Successive Oligopolists." American Ecomomic Review, 69:137-141. 
Grossman, Gene M. and Elhanan Helpman, 2004. "Outsourcing in a Global Economy." Review of Economic Studies, forthcoming.

Hanson, Gordon, 1997. "The Effects of Off-Shore Assembly on Industry Location: Evidence from U.S. Border Cities," in Robert C. Feenstra, ed., Effects of U.S. Trade Protection and Promotion Policies, Chicago: University of Chicago Press, pp. 297-322.

Hanson, Gordon, Raymond J. Mataloni Jr., and Matthew J. Slaughter, 2003. "Vertical Production Networks in Multinational Firms," NBER Working Paper \#9723, May.

Head, Keith and John Ries, 2002. "Offshore Production and skill upgrading by Japanese Manufacturing Firms" Journal of International Economics, October, 58(1):81-105.

Hummels, David, 2001. “Time as a Trade Barrier,” Purdue University Manuscript.

Hummels, David, Jun Ishii and Kei-Mu Yi, 2001. "The Nature and Growth of Vertical Specialization in World Trade," Journal of International Economics, June, V54(N1):75-96.

Krugman, Paul R., 1989. Exchange Rate Instability. Cambridge: MIT Press.

Lee, Jong-Wha, Robert J. Barro, 1997. "Schooling Quality in a Cross Section of Countries," NBER Working Paper \#6918.

Mendez, Jose A., 1993. "The Welfare Effects of Repealing the U.S. Offshore Assembly Provision," Journal of International Economics, 34:1-22.

McLaren, John., 2000. "Globalization' and Vertical Structure," American Economic Review, 90(5): 1239-1254.

Qui, Larry D. and Barbara J. Spencer, 2002. "Keiretsu and Relationship-Specific Investment: Implications for Market-opening Trade Policy," Journal of International Economics, 58(1):4979.

Rauch, James E., 1999. "Networks versus Markets in International Trade," Journal Of International Economics 48(1):7-35.

Riker, David A., and Lael S. Brainard, 1997. "US Multinationals and Competition from Low Wage Countries," NBER Working Paper \#5959.

Schott, Peter K., 2002. "Moving Up and Moving Out: Product Level Exports and Competition from Low Wage Countries," Yale School of Management manuscript.

Swenson, Deborah L., 1997. "Explaining Domestic Content: Evidence from Japanese and U.S. Auto Production in the U.S.," in The Effects of U.S. Trade Protection and Promotion Policies, edited by Robert C. Feenstra. Chicago: University of Chicago Press, 33-53.

Swenson, Deborah L., 2000. "Firm Outsourcing Decisions: Evidence from U.S. Foreign Trade Zones," Economic Inquiry, 38(2): 175-189.

Yi, Kei-mu, 2003. "Can Vertical Specialization explain the Growth of World Trade?" Journal of Political Economy. 111(1):52-102, 2003 Feb. 


\begin{tabular}{|c|c|c|}
\hline & $\begin{array}{l}\text { 1980-90 } \\
\text { Sample }\end{array}$ & $\begin{array}{l}\text { 1991-2000 } \\
\text { Sample }\end{array}$ \\
\hline Argentina & $X$ & $X$ \\
\hline Australia & $\mathrm{X}$ & $X$ \\
\hline Austria & $\mathrm{X}$ & $\mathrm{X}$ \\
\hline Barbados & $\mathrm{X}$ & $X$ \\
\hline Belize & $X$ & $X$ \\
\hline Belgium & $\mathrm{X}$ & $X$ \\
\hline Bangladesh & $X$ & $X$ \\
\hline Bolivia & $X$ & $X$ \\
\hline Brazil & & $X$ \\
\hline Canada & $\mathrm{X}$ & $X$ \\
\hline Chile & $\mathrm{X}$ & $X$ \\
\hline China & $\mathrm{X}$ & $\mathrm{X}$ \\
\hline Colombia & $\mathrm{X}$ & $X$ \\
\hline Costa Rica & $X$ & $X$ \\
\hline Denmark & $\mathrm{X}$ & $X$ \\
\hline $\begin{array}{l}\text { Dominican } \\
\text { Republic }\end{array}$ & $\mathrm{X}$ & $X$ \\
\hline Ecuador & & $X$ \\
\hline El Salvador & $X$ & $X$ \\
\hline Egypt & $X$ & $X$ \\
\hline Finland & $X$ & $X$ \\
\hline France & $\mathrm{X}$ & $X$ \\
\hline Germany & $X$ & $X$ \\
\hline Greece & $\mathrm{X}$ & $X$ \\
\hline Guatemala & $X$ & $X$ \\
\hline Guyana & $\mathrm{X}$ & $X$ \\
\hline Haiti & $X$ & $X$ \\
\hline Honduras & $\mathrm{X}$ & $X$ \\
\hline Hong Kong & $X$ & $X$ \\
\hline Hungary & $\mathrm{X}$ & $X$ \\
\hline India & & $X$ \\
\hline Indonesia & $\mathrm{X}$ & $\mathrm{X}$ \\
\hline Ireland & $X$ & $X$ \\
\hline Israel & $X$ & $X$ \\
\hline Italy & $\mathrm{X}$ & $X$ \\
\hline Ivory Coast & & $X$ \\
\hline Jamaica & $X$ & $X$ \\
\hline Japan & $\mathrm{X}$ & $X$ \\
\hline Jordan & & $X$ \\
\hline Kenya & & $X$ \\
\hline Korea & $\mathrm{X}$ & $X$ \\
\hline Macau & & $X$ \\
\hline Malaysia & $\mathrm{X}$ & $X$ \\
\hline Malta & & $X$ \\
\hline Mauritania & $\mathrm{X}$ & \\
\hline Mauritius & $X$ & $X$ \\
\hline Mexico & $\mathrm{X}$ & $X$ \\
\hline Morocco & $\mathrm{X}$ & $X$ \\
\hline
\end{tabular}

\begin{tabular}{|c|c|c|}
\hline & $\begin{array}{l}\text { 1980-90 } \\
\text { Sample }\end{array}$ & $\begin{array}{l}\text { 1991-2000 } \\
\text { Sample }\end{array}$ \\
\hline Nepal & $X$ & $X$ \\
\hline Netherlands & $X$ & $X$ \\
\hline Norway & $\mathrm{X}$ & $\mathrm{X}$ \\
\hline Oman & & $X$ \\
\hline Pakistan & $X$ & $\mathrm{X}$ \\
\hline Panama & $X$ & $X$ \\
\hline Peru & $X$ & $\mathrm{X}$ \\
\hline Philippines & $X$ & $X$ \\
\hline Poland & $X$ & $\mathrm{X}$ \\
\hline Portugal & $X$ & $X$ \\
\hline Romania & $X$ & $\mathrm{X}$ \\
\hline Sierra Leone & $X$ & \\
\hline Singapore & $\mathrm{X}$ & $X$ \\
\hline Spain & $X$ & $X$ \\
\hline Sri Lanka & $X$ & $X$ \\
\hline St. Kitts Nevis & $\mathrm{X}$ & $X$ \\
\hline Sweden & $X$ & $X$ \\
\hline Switzerland & $X$ & $X$ \\
\hline South Africa & $X$ & $X$ \\
\hline Taiwan & & $X$ \\
\hline Thailand & $X$ & $X$ \\
\hline Trinidad & $\mathrm{X}$ & $\mathrm{X}$ \\
\hline Tunisia & & $X$ \\
\hline Turkey & $X$ & $X$ \\
\hline UK & $X$ & $X$ \\
\hline Uruguay & & $\mathrm{X}$ \\
\hline Venezuela & $X$ & $X$ \\
\hline Vietnam & & $X$ \\
\hline
\end{tabular}

